\title{
USING INNOVATION AND ACTION RESEARCH TO BUILD TESOL TEACHER CAPACITY IN VIETNAM
}

\author{
Martin Benedict Andrew \\ College of Education, Victoria University, Melbourne \\ Email: Martin.andrew@vu.edu.au
}

\begin{abstract}
Critical insights from educational innovation research inform TESOL educators in Vietnam that pedagogical interventions should be particular to their context and environment. This paper presents a qualitative descriptive analysis of four teachers who are students in a Master of Education (TESOL) program delivered in Vietnam by within a partnership between an Australian and a Vietnamese University. The study draws on the assessed work of students in the unit Innovation which aims to encourage its students, all of whom are experienced professional educators, to identify a research problem specific to their teaching and learning environment and design a research question built around a pedagogical or curricular intervention they can ethically implement and evaluate within their workplaces. This activity, serving as both curriculum and assessment, empowers students to apply a segment of an action research cycle to their classrooms. The study presents four narratives of teacher/researchers engaged in innovation research, identifying research problems, developing topics and lines of enquiry and ultimately evaluating their projects reflectively. This pedagogical approach articulates the idea that the best people to know what innovations are required in Vietnamese educational contexts are the teachers themselves. Additionally, the findings support the use of an action research-focused pedagogy as an appropriate approach for use in TESOL programs in such developing nations as Vietnam.
\end{abstract}

Keywords: Innovation, Action Research, TESOL, Teacher Capacity, Vietnam

\section{THE SCOPE OF THE RESEARCH}

This research occurs within the context of a 16-year collaboration in teaching and learning TESOL between a Vietnamese and an Australian university. Responding to changing student, local and national needs, the program has developed into one focusing on teaching Vietnamese educators to become novice action researchers. This means that not only do the students, who are teachers from tertiary, secondary and primary state and private institutions, learn to draw on their own experiences and journeys as practitioners in the creation of new knowledge relevant to their contexts; they also acquire the research skills and reflective techniques to be able to implement further projects in their teaching environments. Some students may even become research leaders, establishing practitioner-based action learning cycles for colleagues. For the purpose of the program, action research is "a small-scale intervention in the functioning of the real world and a close examination of the effects of such intervention" (Cohen \& Manion, 1985, p. 174). Such cycles lead, ideally, to the testing of new pedagogical and curricular innovations, such as those used internationally in TESOL, and evaluate their value and appropriateness to the institutional and national environments where our students teach.

This program is motivated by the ideas that empowering teachers in ELT contexts by enabling them to become action researchers and reflective practitioners is a key strategy in critical pedagogy (Wyatt, 2011) and English Language Teaching (ELT) education (Burns, 2010). Action research contributes "to the increased well being - economic, political, psychological, spiritual - of human persons and communities" (Reason \& Bradbury, 2001, p. 2). Crucially, the curricular delivery does not merely follow precepts from western 
practice. Le Van Canh (2011) writes: "without adequate understanding of what shapes their teaching practices, any coercive intervention to change teachers, including formal training, would be of limited impact" (p. 238).

The work of Vietnamese researchers, both within Vietnam and overseas, informs the program's prescript: "Research, especially classroom research...plays an important role as it can help generate classroom practices which are appropriate to the social, cultural and physical contexts in which they work" (Pham, 2006, p. 2). Further, participatory action research allows teachers "to learn about their teaching at the same time as they improve their teaching" (Tran, 2009, p. 105). Tran writes: "It allows teachers to learn about their teaching at the same time that they improve their teaching." (p. 105). Lillian Utsumi and Doan Thi Nam-Hau (2010) argue that teachers want to change to meet learners' needs by enhancing autonomy, using collaboration and project work and creating discussions stimulating "high order thinking" (p. 14).

To enter the three-unit Masters segment, students need a Diploma in TESOL and IELTS 6.5 or equivalent. Arguably more important than either the content knowledge or linguistic attainment is the students' investment in the experience of a transnational Masters in TESOL. There is a danger of regression. Huang (2010) warned: "During the training courses, Vietnamese teachers show great interest in new methodologies, but after they return from those courses, they continue teaching in old methods" (p. 22). This is the gap Roger Barnard and Gia Viet Nguyen (2010) see as the disjuncture between "intended" innovations in TESOL teaching "and the realized version" (p. 77). The action research-focused curriculum of the MTESOL encourages students to consider what might potentially constrain them from their aspired classroom innovations, and to evaluate the success of their interventions.
The 'capital' of such a program, to draw lightly on Bourdieu's (1988) well-known concept of social, cultural and other forms of value, consists in access to innovative pedagogical and curricular ideas from international literature and from lecturers' own practice, and the chance to explore one's own teaching and learning environment and the practices and culture of one's institution as a starting point for selecting, implementing and evaluating a teaching intervention in a local context. The students with a more integrative motivation to become empowered, to become leaders in their contexts, and to being the best teacher they can are consistently more successful than those with purely instrumental motivation (keeping jobs, pay increases, promotions).

The MTESOL program is delivered three times a year in a fly-in-fly-out delivery model with international lecturers supplemented by local teachers, with students progressing through the three units over the space of 12 months. In their first unit, Educational Research Design and Methods, the students learn how to write literature reviews and how to scope out a potential project in the form of a micro-proposal. An emphasis on ethics and researcher honesty, a compulsory dimension for transnational partners, remains strong throughout the units. This is taught practically in such activities as learning to paraphrase/summarise from literature, and in considering the impact of the planned innovation on each stakeholder. The dimension of power, manifest in the fact that teachers have ultimate power over their students' grades, is crucial in their descriptions of ethical concerns. The program is informed by practitioner research throughout, and as such there is a strong emphasis on reflection: reflection on, in and for action.

The second unit, Innovation, uses innovation sociocultural and social identity theories, to ask students to define what is 
innovative about their project and justify its necessity. Innovation is seen as

An idea, object or practice perceived as new by an individual or individuals, which is intended to bring about improvement in relation to desired objectives, which is fundamental in nature and which is planned and deliberate. (Nicholls, 1983, p. 4, cited in White, 1988, p.

Ideas for Innovation can be entirely new or a reworking of an old idea or an embedding of an old idea into a new context (Markee, 1997). In some contexts, particularly rural ones, using vocabulary games or dictogloss to enhance lexical acquisition may indeed be new; and in others, perhaps private universities with transnational programs, the role of peer intervention in assessing writing or the use of blogging to enhance critical thinking may be appropriate.

In this unit, students design the procedures of data collection and analysis and assess the project's viability, practicality, suitability and ethical integrity. They learn to position themselves within the body of learning and to partake in the academic conversation, developing an integrated proposal and research instruments, delivering them in oral and written forms. They implement their studies, gathering data and envisaging its analysis and presentation it in a way that articulates with their line of enquiry. Thinh Do Huy (2006) wrote of a strong need for institutions to "help learners identify their learning objectives and needs and employ various tasks to stimulate learner motivation" (p. 8).

The final unit, Evaluation, takes the student from the status of collector of raw data to potential author of a research report or article. Learning how to evaluate a range of interventions in TESOL and how to analyse data using tools such as open coding and thematic analysis, students acquire the skills needed to work with and present data. The emphasis is on evaluation and reflection; in particular on identifying aspects of the research process that were or were not successful. Valuable learning emerges from such retrospection; learning not just about research but about the individual's capacity and the practitioner's drive for continual improvement. The final report not only captures the academic literacies demanded of professional writing in TESOL, but also represents a learner's trajectory as an action researcher.

\section{CONTEXTS FOR EDUCATIONAL INNOVATION IN TESOL IN VIETNAM}

During the past 15 years, the program has resisted remaining a static product and has evolved to match national initiatives such as the 2020 program, institutional drives like Hanoi university's desire to maximize its TNE opportunities, and educational motivators like the absorption of ideas from communicative language teaching (CLT) into a broader church informed by critical, post-structural, social constructivist, and sociocultural thinking which regard learners as individuals with changing investments in learning related to their desires for future imagined communities of belonging (Kanno \& Norton, 2003); and more fluid identities as socially mobile national and global community members (Norton, 2000). As in Bonny Norton's work, there is a stronger focus on learning as capital, as power, and on English as a locus of power: the more privileged access to English, the more valuable as an individual you are to yourself, your school, your family, your country. Access to 'English' is a crucial motivator in terms of students' desires for future recognition, promotion, leadership opportunities and other forms of social and cultural capital. This trend is evident in recent writings on education in Vietnam, such as Johnathan D. London's compilation of studies (2011, pp. 2-3): 
Over the last two decades, Vietnam has registered significant "improvements" across many indicators of educational development.

Education in Vietnam - as in other countries - has long been viewed as a pathway to a better life; an avenue to social mobility.

The pressure on education to serve as a vehicle of individual and collective advancement is more acute than ever as society becomes more complex and globally integrated.

Vietnam's education system may be thought of as a vast social field in which aspirations and constraints collide.

These fragments of text indicate the key problem that students in the MTESOL face: the pressure of constraints. Pham (2006) noted there is difficulty in resisting top-down, power-coercive structures in institutions. Nguyen (2011) signaled: "The issues of research as well as the values of research are not determined by the researcher but instead by the sponsor" (p. 242). Many teachers are fearful of changing their methods (Tomlinson \& Bao, 2004) and to emphasise the spoken and aural skills demanded for communication in a globalised world - but untested by national college examinations (Canh \& Bernard, 2009). London (2011) writes: "quite often, entrenched interests, bureaucratic rigidities, and ideological functionalism seem only to promote continued organisational inertia" (p. 3). The innovation students are encouraged to implement can clash with this 'inertia'.

These top-down constraints, students report, come fin primary and secondary contexts from "didactic" textbooks (Canh \& Barnard, 2009, p. 23), layered with pedagogical methods that are communicative in principle but may not be in practice
(Barnard \& Nguyen, 2010). Barnard and Nguyen suggest this could be due to teachers' inability to implement the intended curriculum. The student teachers in the MTESOL, however, consistently argue it is due to the kinds of bureaucratic rigidities London (2011) pinpoints. For MTESOL students, the challenge is, to cite Alastair Pennycook (2001) "finding possibilities of articulation" (p. 130). These possibilities have limitations, as Iranian scholars Reza Pishghadam and Elham Naja Meidani (2012) discovered in their introduction of tenets from critical pedagogy into a curriculum on postmodern philosophy: "Getting students acquainted with critical issues is like opening a Pandora's box, having detrimental effects on students' lives" (p. 477). To take a critical approach to action research in Vietnam still opens such a box. Defining the limits of possibility is a negotiation between student, teacher and researcher within their environment and depends upon a willingness to improve students' learning for their imagined future communities and identities. Accepting there are new or other ways remains a constraint.

These constraints also originate in school leaders such as Deans and Principals whose conceptions of education have not kept pace with the rhetoric of governmental policy. The Government, Decision No. 1400/QĐ-TTg, the report Teaching and learning foreign languages in the national education system, period 2008-2020 (2008), for instance, set a future-focused goal for language education

To renovate thoroughly the tasks of teaching and learning foreign language within the national education system, to implement a new program on teaching and learning foreign language at every school level and training degree, which aims to achieve by the year 2015 a vivid progress on professional skills, language 
competency for human resources, especially at some prioritized sectors; by the year 2020 most Vietnamese youth graduate from vocational schools, colleges and universities are to gain the capacity to use a foreign language independently (cited in Nguyen, 2011, p. 29).

The MTESOL aims to provide the kind of 'vivid progress' the policy outlines and to empower its students, Vietnam's teachers, not only with capacity to use English independently, but also to research their practice with agency. Drawing on insights from such contemporary theories as critical pedagogy, teachers use their own experience to critique classroom events and theorize about what they observe (Pennycook, 2004). Arguably, this allows them to recognise their place in a system of oppressive relations and to establish 'liberatory praxis', born partly of enacting a process of "reflection and action upon the world in order to transform it" (Friere, 1970, p. 33). To do this involves, as Ramin Akbari (2008), suggested, a call to attend to "the messy, unpleasant aspects of social life” (p. 282), including students' reallife concerns and basing learning as much as possible on students' local culture while creating awareness of the marginalised who might be the students themselves or the students' students.

The program involves investigation into learners' power to act. It is important, Pham (2006) maintains, "to investigate how English language teachers think the context in which they work shapes their aspirations, research practices and outcomes" (p. 8). In collaboration with lecturers and with their peer community, students design an initial research question, which is developed into a line of enquiry. This draws on critical friends group (CFG) protocols (Vo \& Nguyen, 2009) and Le's (2011) belief that the best approaches "Vietnamese collectivism" (p. 244) and the desire for "social harmony" (Nguyen, 2011, p. 26). Vo and Nguyen (2009) write: "Through the social interaction of discussion, active learning evolves, and each participant interprets, transforms, and internalises new knowledge as a result of collective thinking" (p. 207). From this dialogic, community-based position, students design and propose an innovation that can be implemented ethically and manageably within their workplaces.

\section{METHODOLOGICAL APPROACH}

This paper is a pilot study to a larger project involving 40 graduated students from the MTESOL investigating the impact of the pedagogical approach outlined above to the students' spheres of endeavour and their identities as teacher/researchers. Theoretically, the study is informed both by people-centred capacity building via development (Sen, 1999) and second language identity construction (Norton, 2000; Phan, 2008). Because case studies offer a nuanced yet holistic view of context-dependent experience while focusing on researchers' learning (Flyvbjerg, 2006, p. 223), the broad approach is a case study.

In the next section, however, four descriptions of pedagogical interventions undertaken by students/educators/researchers in their contexts are outlined. These students have given consent for their coursework to be used as data. Although the names are pseudonyms, there is little risk if the students are identified through their functions and their institutions, both central to their topics. All students believe others can learn by considering their cases.

This study adopts a form of maximum variation sampling, albeit from a small sample and acknowledges this as a limitation. While the discussion above demonstrates the background, this naturalistic enquiry neither works on preselected variables nor has an $a$ 
priori commitment to any theoretical view of a target phenomenon.

Methodologically speaking, the paper presents a descriptive qualitative analysis (Sandelowski, 2000) or "interpretive description" (p. 335), informed by subjective academic analysis (Arnold, 2011) because epistemologically my own story is inseparable from those of my students. In this methodology, "the description in qualitative descriptive studies entails the presentation of the facts of the case in everyday language“" (Sandelowski, 2000, p. 336). Summarising and 're-presenting' the informational content of the data is, in this methodology, a means of analysis.

\section{FOUR INNOVATIONS \\ Case 1: Phuong}

Phuong chose as her topic 'Improving the English speaking competency of low level adult students using task repetition: A case study at Vietnam Air Defense and Air Force Academy'. With the research question 'in what ways can task repetition improve my learners' accuracy and fluency in their English oral performance?' she produced a qualitative case study focusing on corrective feedback, an intervention pertinent to her specific context. She identified her research problem thus:

Although various solutions were suggested in...articles, only task repetition is believed to be able to possibly minimize these two major facets of my EFL students' oral imperfection.

Describing the implementation of her study, she wrote that students narrate a story and are video-captured. Students then transcribe the story, correct errors autonomously, peer correct, and finally the teachers corrects the transcription herself. Next, the students repeat the process attending to self-correction. To enhance students' awareness, a reflective diary is kept throughout. Her description of her study contains much researcher awareness. She identifies as potential contextual issues technophobia and unfamiliarity with 'reflection', problems requiring proactive preteaching. She realizes, too, that there is a need for her as teacher to model the (i) speech and transcription and (ii) the appearance of 'reflective' journals. As a researcher she aims to analyse the sets of transcripts and read the reflective logs thematically, applying constant comparison and reading for synonyms. She writes that these methods help to add rigour. She is aware of the limitations of such an approach: the data is largely self-reported; the students in her class are multi-level - and all male.

Her evaluative reflections on her study demonstrate her growth as an action researcher:

The influence of task repetition on accuracy could have been more effective if the students had been presented [with] and had practiced those linguistic features more profoundly earlier in the course.

Some minor decrease in anxiety was also observed, yet there should be more similar practice in the future in order to achieve significant improvements in this affective variable.

It was hoped that this small-scale study would set foundations for my future innovations, and that by means of gaining such little changes over the course, my students would consequently make substantial gains in the foreign language.

Phuong positions herself here less as the teacher than as the budding researcher, ready and willing to learn from this action research subcycle and to work as a teacher/researcher with future interventions for her student body. 


\section{Case 2: Duc}

Students' topics typically describe an innovation, characterize a goal, specify a context and identify a target group. This is true of Duc's: 'Using group work with peer assessment to improve the English speaking skill of second year non-English major students at [city] University of Business and Technology'. The specificity makes the innovativeness of the project all the more evident.

Research questions have criteria too: they result from contextual analysis; are related to a student's practice; are foregrounded by recent literature; understand the range of stakeholders in the project, and can be potentially generalizable. Duc asks: 'In what way does group work with peer assessment affect sophomores' participation and interaction?' He understands he is using an action research sub-cycle to understand people and phenomena and that his focus is the impact of peer assessment. The problem that led to this question is also understood: Students lack critical or reflective insight into the metalinguistic aspects of lexical and phonological improvement and exhibit passive behaviours.

The implementation is described in his proposal: Weekly group work activities either case studies or role plays - are observed over five weeks and after each session students are interviewed. Then students will participate in peer assessment using a specially-designed form commenting on others' engagement, speaking time, turntaking and other forms of involvement. Duc is aware that one problem is the difficulty of investing individuals in group work when the assessment structure is necessarily individual. As a teacher, he needs to encourage them to be natural and not forced during interviews, Like Phuong, as a researcher he aims to analyse the sets of observation data and read the interview transcripts thematically. To ensure interpretative validity, he writes that a colleague will check his questions. $\mathrm{He}$ is passionate but fears his current class may be lacking in linguistic proficiency, partly because they are non-English majors, and fears a backlash against him ("tôn su trọng đạo"). There may be, he thinks, difficulty in generalizing from his sample and is aware of the ethical conflict of teacher as interviewer and assessor. Expecting teacher marking, these learners are not equipped for autonomy. Nevertheless, Duc is positive in his evaluation of his intervention, while at the same time aware of what he needs to do differently next time:

Using peer assessment in group work solved my students' problems of disengagement, poor interaction in group work and increased students' English talking time.

If I have a chance to do the research again, I will analyse the data as soon as I collect them or analyse them weekly instead of waiting for all data to be collected. In order to create and increase students' interest in taking part in activities, the activities should be interesting, familiar to real life and appropriate to students' level.

Clearly a confident teacher, he offers reflective insights relates to what he learned about himself as an action researcher and a motivator of students in their roles as participants.

\section{Case 3 Huang}

Spoken narration is one of the most popular topics for innovation-based research in the MTESOL, and Huang's topic is typical: 'Using storyline techniques to promote young learners' fluency in speaking at [name] Education and Training Center'. The skill of speaking is also the one most under the microscope, with Huang's question being 'To what extent does the storyline technique 
improve students' fluency in speaking?' This question arose from her autoethnographic identification of one concern in her context: due to grammar-focused instruction, young learners lack fluency in and beyond the classroom. The focus of her work is the storyline method (Ahlquist, 2012) incorporating the oral potential of storytelling, picture describing, story-unfolding and impromptu role-playing, all techniques suitable for young learners. Huang describes her approach as an action research arc producing data analysed using 'indigenous' thematic analysis.

Huang took a curricular view to the implementation of her innovation. Over 12 weeks and during 180-minute classes, storyline activities are introduced weekly. Despite ethical discussion about taping children, Huang planned to videotape the sessions to collect 'empirical data'. She triangulated this data with her reflective notes as teacher-researcher and with transcripts of student interviews. She was worried students' memories might not be sufficient, or that they might freeze in an interrogatory context where the power relations between themselves and their 'teacher' were dynamically different. She was prepared to collect sufficient data to ensure reliable results, and she was attuned to emphasising the subjective interrelationship between researched and researched and the fact that young learners offer instinctive rather than insightful responses. She was adamant both her principal and her participants' parents would sign letters of consent, and that interviews would be supervised by an adult.. Huang's evaluation of the value of storybook techniques was positive, and it closely followed Sharon Alquist (2012). She is, however, aware of the ethical dimension of herself as teacher and researcher, and how this duality might be more significant in studies with young children than with adults:

The paper recommends other types of speaking activities, which may be beneficial for upgrading students' speaking skills, such as presentation, creative games, films and songs, and group discussion. These activities might not only improve the skills, but also fulfill the test-driven curricula in Vietnam.

I view this intervention is unsuccessful considering all the key issues and other additional factors...All the plays that I selected for them seem to exceed their endurance...I also have to pay more attention in training my skills both as a researcher and a practitioner before carrying out any more studies.

\section{Case 4: Miriam}

The topic 'Educational games: One answer to the vocabulary teaching and learning problem in an $8^{\text {th }}$ grade [city] Bilingual School' immediately presents the research problem, which Miriam also sees as being related to a Vietnamese mindset that learning cannot be 'fun' and constructivism is not appreciated by principals. To paraphrase Miriam (a non-Vietnamese), lexical shortfall is a major obstacle to speaking and ongoing resistance to new pedagogies limits the nature of appropriate innovations. Communicative games, however, she says, replicate a Vygotskian sociocultural context where safe learning can occur. Miriam asked two questions, both of which are open to naturalistic qualitative enquiry:

- In what ways do games impact vocabulary teaching and learning?

- What are the students' perceptions of the use of games?

Miriam's methodological approach was consistent: Qualitative analysis of observation sheets, student reflections and interview transcripts from interviews on two days of 
game-intensive lessons. As a researcher, she aimed to analyse transcripts applying insights from grounded theory; to read the reflective logs using the constant comparison method, and to elicit different perspectives from the perceptions of colleague teachers who acted as observers. Concerned with interpretative validity, she maintained a focus on a "highly contextualized understanding of the phenomena" via triangulation and using colleagues as interviewers. Miriam was aware of ethical distance between the researcher and the participants, and of a common limitation of working with young participants: they might say what they believe the teacher/researcher wants to hear. To triangulate this over-reliance on insider perspectives, she uses her colleagues as interviewers but not, unfortunately, observers.

The implementation of her project was straightforward: Across lessons addressing all skills, the teacher introduces two periods of games-rich sessions over an 8-week period and collects contrastive data. Simultaneously, students keep journals as homework in response to narrative frames. To prepare the students, she provides a pilot lesson to demonstrate the purpose of games and explain the procedures.

Miriam draws both specifically contextual and general conclusions from her study:

The innovation was a success because games created a potential change in the students' mindset from English language classroom and vocabulary lessons as boring to being interactive classroom.

Educational vocabulary games are capable of enhancing a learner's motivation in vocabulary acquisition.

Using vocabulary games in the classroom creates a relaxing, exciting and conducive atmosphere for learning.
The research tools used were not very effective, as it was hard to take notes as a participant observer and observe facial expressions in informal talks as well as write.

Miriam may be overly critical of her discovery that to observe and to write is complex, and would use colleagues next time, but her empirical findings bear out what literature on the use of games has long known. To her, and to her school, seeing the children engaged in a 'funny' activity changed perspectives on the line between study and play.

\section{CONCLUSIONS}

Reports of what actually happens in TESOL classrooms in Vietnam are few (Barnard \& Nguyen, 2010) so studies of this nature that contribute embodied descriptions of innovation in action add to the literature on the disjuncture between rhetoric and action in Vietnamese ELT education. Le Van Canh frequently indicates a problem with the undertraining of teachers (Canh \& Bernard, 2009); this study articulates a situated pedagogical approach that can change that. This study is one of the first exploring the value of action research as a tool for giving teachers a voice for decision- and policy-makers to heed as Vietnam and other nations in the South East Asian boom-zone in alliances with Australia and other nations (Cambodia, Myanmar, Thailand, The Phillipines, Laos, Indonesia and so on) continue to innovate their language teaching curricula and practices in an age characterized by global movement (Canh \& Bernard, 2009), desire for self betterment (London, 2011), aspiration for future communities (Kanno \& Norton, 2003) and complex identities in flux (Norton, 2000).

The program of action/practitioner research presented within the MTESOL described here offers teacher/practitioners opportunities to investigate their specific 
contexts and develop their own needs while satisfying the requirements of workplaces. There are further advantages in terms of procedural and ontological knowledge. Such a teacher education program enables learners to apply the tools of professional practice as research and potentially to become 'champions' in their educative contexts. Importantly, it allows them to research in a way that is culturally appropriate in the case of Vietnam, using applicable methodological tools and techniques. Although the tenets of postcolonial theory and critical pedagogy inform the delivery of the program, there is far to go before local teachers can feel safe with either introducing innovative techniques into classrooms or to introduce a critical approach to textuality. This could be due to the highly instrumentalist, examinationfocused orientation of English language curricula, particularly in Vietnamese schools (Barnard \& Nguyen, 2010) or to resistance to reforms perceived as top-down (Canh \& Barnard, 2009). These observations are not unique to Vietnam, and may be applicable to bilateral collaborations with the nations listed above.

In any context, although clearly this study has been a Vietnamese one, empowering teacher educators as action researchers is an approach that can help teachers 're-cognise' their own place in a system of oppressive relations such as their teaching institutions. They can seek "possibilities of articulation" (Pennycook, 2001, p. 130) and potentially establish a critical consciousness that may contribute to what Freirean liberatory praxis, powered by "action and reflection on the world" (1970, p. 60). The teacher/researchers in this study did take action, albeit safe action, and their reflections reveal that not only did they add value to their students' targeted learning; they also learned much about their capacity as change agents.

Many of the most successful innovations are those that draw on Wengerian social constructivist ideas of learning via collaboration and apprenticeship. While Miriam felt her school was unprepared to explore the nexus between lexical learning and social play, much local research emphasises the value of tasks that rely on collaboration, as in Huang's task-based storyline method and Duc's intervention in peer assessment despite his fear that the collective might clash with the individual. Contrary to stereotypes about teacher-fronted education (Phan, 2004), working in groups is impactful in Vietnamese teacher education as in Vo and Nguyen's (2009) critical friends pedagogy. Phan (2008) describes the ethic that "human relationships are at the core of the care orientation" (p. 7) and that "belonging" is a crucial aspect of investment (p. 13). Le (2007) wrote that "Vietnamese collectivism" (p. 244) is a key to moving forward in TESOL education in Vietnam and Nguyen (2011) note that regard for "social harmony" (p. 26) can be an asset. There continues to be a need to investigate the potential of community of practice pedagogies in education in Vietnam and to examine in detail what teachers' capacities truly could be.

\section{REFERENCES}

Akbari, R. (2008). Transforming lives: Introducing critical pedagogy into ELT classrooms. ELT J 63(3), 276-283. Retrieved December 1, 2013 from http://dx.doi.org/10.1093/elt/ccn025

Alquist, S. (2012). 'Storyline': a task-based approach for the young learner classroom. ELTJ, 67(1), 41-51. Retrieved December 1, 2013 from http://dx.doi.org/10.1093/elt/ccs052

Arnold, J. (2011). The self as data: A qualitative methodology. Journal of Educational and Developmental Psychology 11(1), 65-73.

Barnard, R., \& Nguyen, G. V. (2010). Taskbased language teaching (TBLT): A Vietnamese case study using narrative 
frames to elicit teachers' beliefs. Language Education in Asia, 1, 77-86. Retrieved December 1, 2013 from http://dx.doi.org/10.5746/LEiA/10/V1/A0 7/Barnard_Nguyen

Bourdieu, P. (1986). Forms of capital. In J. G. Richardson (Ed.), The Handbook of theory and research for the sociology of capital (pp. 241-58). New York, NY: Greenwood Press.

Burns, A. (2010). Doing action research in English language teaching. New York: Routledge.

Canh, L.V., \& Barnard, R. (2009). Curricular innovation behind closed classroom doors: A Vietnam case study. Prospect, 24(2), 20-33.

Canagarajah, S. (2005). Critical pedagogy in L2 learning and teaching. In E. Hinkel (Ed.), Handbook of research in second language teaching and learning (pp.931949). Mahwah, NJ: Lawrence Erlbaum.

Cohen, D. K., \& Manion, L. (1985). Research methods in education. London: Croom Helm.

Freire, P. (1970). Pedagogy of the oppressed. Harmondsworth, UK: Penguin.

Flyvbjerg, B. (2006). Five misunderstandings about case-study research. Qualitative Inquiry, 12(2), 219-245. Retrieved December 1, $2013 \quad$ from http://dx.doi.org/10.1177/1077800405284 $\underline{363}$

Kanno, Y., \& Norton, B. (2003). Imagined communities and educational possibilities: Introduction. Journal of Language, Identity and Education, 2(4), 241-249. Retrieved December 1, 2013 from http://dx.doi.org/10.1207/S15327701JLIE 0204_1

Le V. C. (2009). Form-focused instruction: A case study of Vietnamese teachers' beliefs and practices. (Unpublished doctoral thesis). Hamilton, NZ: University of Waikato.
London, J. D. (2011). Education in Vietnam. Singapore: Institute for Southeast Asia Studies.

Markee, N. (1997). Managing curricular innovation. Cambridge, UK: Cambridge University Press:

Nguyen, N. (2011). West wind blows: Voices of Vietnamese teachers and students of English- a case study of Nha Trang University. (Electronic Thesis or Dissertation). Retrieved December 1, 2013 from https://etd.ohiolink.edu/

Norton, B. (2000). Identity and language learning. London: Longman.

Pennycook, A. (2001). The politics of pedagogy. In A. Pennycook (Ed.), Critical applied linguistics: A critical introduction. (pp. 114-140). New Jersey: Lawrence Erlbaum Associates.

Pham, H. H. (2006). Researching the research culture in English language education in Vietnam. TESL-EJ 10(2), 1-20. Retrieved December 1, 2013 from teslej.org/ej38/a10.

Phan, L. H. (2004). University Classrooms in Vietnam: Contesting the Stereotypes. ELT Journal, 58(1), 50-57.

Phan, L. H. (2008). Teaching English as an International Language: Identity, Resistance and Negotiation. Clevedon, UK: Multilingual Matters.

Pishghadam, R., \& Meidani, E.N. (2012). A critical look into critical pedagogy. Journal for Critical Education Policy Studies, 2(2), 464-484.

Reason, P. , \& Bradbury, H. (2001). Introduction: Inquiry and participation in search of a world worthy of human aspiration. In P. Reason \& H. Bradbury, (Eds.), Handbook of action research: Participatory inquiry and practice (pp. 114). New Delhi: Sage.

Sandelowski, M. (2000). Focus on research methods: Whatever happened to qualitative description? Research in Nursing \& Health, 23, 334-340. 
Sen, A. (1999). Commodities and capabilities. India: OUP India.

Thinh, D. H. (2006). The role of English in Vietnam's foreign language policy: A brief history. Proceedings of $19^{\text {th }}$ Annual EA Conference. English Australia. Retrieved December 1, 2013 from http://qa.englishaustralia.com.au/index.cgi ?E $=$ hcatfuncs $\& \mathrm{PT}=\mathrm{s} 1 \& \mathrm{X}=$ getdoc $\&$ Lev $1=$ pub_c07_07\&Lev2 $=$ c06 thinh

Tomlinson, B., \& Bao, D. (2004). The contributions of Vietnamese learners of English to EFL methodology. Language Teaching Research, 8(2), 199-222.

Tran, T. T. H. (2009). Why is action research suitable for education? VNU Journal of Science, Foreign Languages 25, 97-106.

Utsumi, L., \& Doan T. N. (2010). Trends in teaching and learning English in Vietnam: Implications for the future. Traversing Borders: Viet Nam Teacher Program. vnu.edu.vn/eng/coe/conference2009/9.Anh. $p d f$

Vo, L. T., \& Nguyen, H. T. M. (2009). Critical friends group for EFL teacher professional development. ELT Journal
64(2), 205-213. http://dx.doi.org/10.1093/elt/ccp025

White, R. V. (1988). The ELT curriculum: Design, innovation and management. Oxford: Blackwell.

Wyatt, M. (2011). Teachers researching their own practice. ELT Journal 65(4), 417-425. http://dx.doi.org/10.1093/elt/ccq074

Senge, P. M. (1997). The fifth discipline. Measuring Business Excellence, 1(3), 4651.

Firman, H., \& Tola, B. (2008). The future of schooling in Indonesia. Journal of International Cooperation in Education, 11(1), 71-84.

Virta, A. (2015). "In the middle of a pedagogical triangle"-Native-language support teachers constructing their identity in a new context. Teaching and Teacher Education, 46, 84-93.

Walsham, G. (1995). Interpretive case studies in IS research: nature and method. European Journal of information systems, 4(2), 74-81. 